\title{
Histomorphometric Changes of Pancreatic Islets with Advancing Age - A Postmortem Study in A Bangladeshi Male Population
}

\author{
Shahriah S, ${ }^{1}$ Nurunnabi ASM, ${ }^{2 *}$ Begum $G N,{ }^{3}$ Kabir $R^{4}$ \\ ${ }^{1}$ Department of Anatomy, Z. H. Sikder Women's Medical College, Dhaka, Bangladesh, ${ }^{2}$ Department of Anatomy, \\ Dhaka Medical College, Dhaka. Bangladesh, ${ }^{3}$ Department of Anatomy, Anwer Khan Modern Medical College, Dhaka. \\ Bangladesh. ${ }^{4}$ Department of Physiology, Z. H. Sikder Women's Medical College, Dhaka, Bangladesh
}

\footnotetext{
*Corresponding Author:

Dr. Abu Sadat Mohammad Nurunnabi,

Lecturer, Department of Anatomy,

Dhaka Medical College, Dhaka-1000. Bangladesh.

Email: shekhor19@yahoo.com

\section{Citation}

Shahriah S, Nurunnabi ASM, Begum GN, Kabir $R$. Histomorphometric Changes of Pancreatic Islets with Advancing Age - A Postmortem Study in A Bangladeshi Male Population. Nepal Journal of Medical Sciences 2014;3(1):63-7.
}

\begin{abstract}
Background: We proposed this study to see the difference in number and diameter of the islets of Langerhans of the pancreas with increasing age in Bangladeshi males, as male population is more prone to diabetes mellitus than female.
\end{abstract}

Methods: This cross-sectional, descriptive study was done in the Department of Anatomy, Dhaka Medical College, Dhaka, from August 2005 to December 2006, based on collection of 75 postmortem male human pancreas. The collected samples were divided into seven age groups: A (10-19 years), B (20-29 years), C (30-39 years), D (40-49 years), $\mathrm{E}$ (50-59 years), $\mathrm{F}$ (60-69 years) and $\mathrm{G}$ ( $\geq 70$ years). In histological slides, number of islets of Langerhans was measured by point counting technique per unit area of microscopic field and diameter by using ocular and stage micrometer.

Results: The number of islets per unit area of the head of the pancreas were $1.40 \pm 0.55,1.80 \pm 0.45,1.40 \pm 0.55,1.00 \pm 0.00,1.80 \pm 0.45,1.00 \pm 0.00$ and $1.20 \pm 0.45$; in the body $1.20 \pm 0.45,2.40 \pm 0.45,2.00 \pm 0.00,2.50 \pm 0.55$, $2.40 \pm 8.90,2.20 \pm 0.45$ and $2.00 \pm 0.00$; in the tail region $2.40 \pm 0.55$, $3.00 \pm 1.22,2.40 \pm 1.34,2.80 \pm 0.84,3.00 \pm 1.22,2.80 \pm 0.84$ and $3.20 \pm 0.45$ in group A, B, C, D, E, F and G respectively. The diameter of pancreatic islets were found $82.64 \pm 0.73 \mu \mathrm{m}, 96.32 \pm 0.91 \mu \mathrm{m}, 108.52 \pm 8.76 \mu \mathrm{m}$, $135.20 \pm 8.38 \mu \mathrm{m}, 134.36 \pm 4.46 \mu \mathrm{m}, 102.40 \pm 0.89 \mu \mathrm{m}$ and $97.20 \pm 2.00 \mu \mathrm{m}$ in group A, B, C, D, E, F and G respectively.

Conclusion: The number of the islets was much higher in tail than that of other regions. However, the diameter of the islets was found to increase up to 49 years and later decreased.

Keywords: Pancreas, Islets of Langerhans, Histomorphometry. 


\section{Background:}

The Endocrine pancreas is a diffuse organ scattered as small nest of cells called islets of Langerhans, which is usually numerous in tail region of the pancreas. ${ }^{1}$ Islets secrete hormones that regulate blood glucose levels. ${ }^{2}$ Pancreatic islets may contain a few cells or many hundreds of polygonal cells arranged in short irregular cords that are profusely invested with a network of fenestrated capillaries. ${ }^{3}$ In haematoxylin and eosin ( $\mathrm{H} \& \mathrm{E})$ stained sections, the islets of Langerhans appear as cluster of pale staining cells surrounded by more intensely staining pancreatic acini. ${ }^{3,4}$ The pancreatic islet function is closely associated with the morphologic changes in islet cells. ${ }^{5}$ The most common disease of the endocrine pancreas is diabetes mellitus associated with changes in the size and number of islets. ${ }^{6,7}$ Moreover, male population predominantly suffers from diabetes mellitus. ${ }^{2}$ The most promising research for diabetes mellitus is in producing stem cells where researchers are looking to make possible for diabetics to have a new pancreas. ${ }^{7}$ Recently, islet cells were successfully generated in vitro from human pancreatic stem cells. ${ }^{8}$

However, sufficient investigation has not been made into how many islets are contained in a unit volume of pancreas, or how differently they behave in their size distribution and still there are scopes to gain insight into their functional relationships and changes in disease process. ${ }^{9}$ Scientists have made many advances in islet transplantation in recent years. However, most recipients returned to using insulin because the transplanted islets lost their ability to function over time. Besides, the researchers also noted that many transplant recipients were able to reduce their need for insulin, achieve better glucose stability, and reduce problems with hypoglycemia. ${ }^{10}$ Another important point is that large amounts and excellent viabilities of pancreatic islets are prerequisites for recent advances in islet transplantation. Cryopreservation has been shown to enlarge transplanted cell mass, but has been accompanied by reduced viability, where a negative correlation between islet size and viability observed in non-frozen islets. ${ }^{11}$ Hence, the present study was designed to see the age related histological changes in pancreatic islets in a Bangladeshi male population. The results of the present study are expected to be helpful in correlating its functional capacity for further research in basic science and in decision making in clinical settings especially in transplant surgery.

\section{Methods:}

This cross-sectional, descriptive study was done in the Department of Anatomy, Dhaka Medical College, Dhaka, from August 2005 to December 2006, based on collection of 75 postmortem male human pancreas aging from 10 to 76 years, excluding any apparent signs of decomposition of the viscera, any injury in pancreas, death due to poisoning and known pancreatic disease. The collected samples were divided into seven age groups: A (10-19 years), B (20-29 years), C (30-39 years), D (40-49 years), E (50-59 years), F (60-69 years) and $G$ ( $\geq 70$ years), for convenient description of their various age related changes (according to Varley et al.). ${ }^{12}$

Preparation of the slides: Selection of the tissue was done according to Wolfe-Coote $\&$ duToit, ${ }^{13}$ and $3 \mathrm{~mm} \times 3 \mathrm{~mm}$ were cut with scissors for histological study (table 1). The histological slides were prepared by using standard procedure with Harris' Haematoxylin and Eosin (H \& E) stain.

Table 1. Location of the tissues collected from each sample ${ }^{13}$

\begin{tabular}{|c|c|c|c|}
\hline Part & Tail & Body & Head \\
\hline Area & $\begin{array}{l}1 \text { inch proximal } \\
\text { to tail end from } \\
\text { horizontal portion } \\
\text { of pancreas } \\
\text { lateral to superior } \\
\text { mesenteric vessels. }\end{array}$ & $\begin{array}{l}\text { Apparently } \\
\text { central } \\
\text { region. }\end{array}$ & $\begin{array}{l}\text { Portion lying } \\
\text { between } \\
\text { inner curve of } \\
\text { second part } \\
\text { of duodenum } \\
\text { and superior } \\
\text { mesenteric } \\
\text { vessels. }\end{array}$ \\
\hline
\end{tabular}

Counting of number of islets of Langerhans in different regions: Five best prepared slides were taken from each of the regions (i.e. head, body and tail), from each group. Thus a total of 105 slides were observed. For the purpose of counting the number of islets, the slide was viewed under low magnification $(\times 10$ objectives, $\times 10$ eyepiece $)$. The average number of islets per unit area of microscopic field for each slide was calculated and their mean is recorded.

\section{Measurement of average diameter of islets of Langerhans:}

For measurement of diameter of islets of Langerhans, five slides were selected, taken from tail region, from each group (as islets are more densely populated in the tail region of the pancreas $\left.{ }^{1}\right)$. Hence, a total of 35 slides of tail region were examined under low magnification $(\times 10$ objectives, $\times 10$ eyepiece). The diameter of islets of Langerhans was measured by using a stage micrometer and ocular micrometer. Two measurements were taken for each of islets of Langerhans. One measurement was taken at the maximum transverse diameter of islets and the other was perpendicular to the previous one. Hence, the transvertical diameter of the islets of pancreas was measured by taking the mean of the two diameters as follows: 
Average diameter $=$ (Maximum transverse diameter + Maximum perpendicular diameter $) \div 2$

The stage micrometer calibration was focused under 10 objective and the ocular micrometer calibration was super imposed on them in such a way that the starting mark on the ocular micrometer matches exactly with the starting mark on the stage micrometer. Then the marker on the stage and ocular micrometer that corresponds to each other most closely was noted. In this way, determination of how many of the smallest division of the ocular micrometer corresponded with how many of the smallest division of the stage micrometer was done. Then the calculation was done to determine the average diameter of the islets of pancreas.

Statistical processing of data: Data were collected and appropriate statistical analyses were done by using SPSS version 11.0, as one-way ANOVA test and multiple comparisons were done by Posthoc in LSD (least significance difference).

Ethical clearance: The present study was approved by the Ethical Review Committee of Dhaka Medical College, Dhaka.

\section{Results:}

Number of Islets of Langerhans in the head of the pancreas: The mean number of islets in the head of the pancreas were $1.40 \pm 0.55,1.80 \pm 0.45,1.40 \pm 0.55,1.00 \pm 0.00,1.80 \pm 0.45$ and $1.00 \pm 0.00$ and $1.20 \pm 0.45$ in group A, B, C, D, E, F and G respectively. The differences were statistically significant in B vs D, B vs F, B vs G, D vs E, E vs F and E vs G (table 2).

Number of Islets of Langerhans in the body of the pancreas: The mean number of islets in the body of the pancreas were found $1.20 \pm 0.45,2.40 \pm 0.45,2.00 \pm 0.00,2.50 \pm 0.55$, $2.40 \pm 8.90,2.20 \pm 0.45,2.00 \pm 0.00$ in group A, B, C, D, E, $F$ and $G$ respectively. The differences were statistically significant in A vs B, A vs C, A vs D, A vs E, A vs F and A vs $\mathrm{G}$ (table 2).

Number of Islets of Langerhans in the tail of the pancreas: The mean number of islets of in the tail of the pancreas in different group was $2.40 \pm 0.55,3.00 \pm 1.22,2.40 \pm 1.34$, $2.80 \pm 0.84,3.00 \pm 1.22,2.80 \pm 0.84$ and $3.20 \pm 0.45$ in group A, B, C, D, E, F and G respectively. No significant differences were found among groups (table 2).

Diameter of Islets of Langerhans in the tail of the pancreas: The average diameter of pancreatic islets were found $82.64 \pm 0.73 \mu \mathrm{m}, \quad 96.32 \pm 0.91 \mu \mathrm{m}, \quad 108.52 \pm 8.76 \mu \mathrm{m}$, $135.20 \pm 8.38 \mu \mathrm{m}, \quad 134.36 \pm 4.46 \mu \mathrm{m}, \quad 102.40 \pm 0.89 \mu \mathrm{m}$ and $97.20 \pm 2.00 \mu \mathrm{m}$ in group A, B, C, D, E, F and G respectively. The differences between the diameter of pancreatic islets were statistically significant in A vs B, A vs C, A vs D, A vs $\mathrm{E}, \mathrm{A}$ vs $\mathrm{F}, \mathrm{A}$ vs $\mathrm{G}, \mathrm{B}$ vs $\mathrm{C}, \mathrm{B}$ vs $\mathrm{D}, \mathrm{B}$ vs $\mathrm{E}, \mathrm{C}$ vs $\mathrm{D}, \mathrm{C}$ vs $\mathrm{E}$, $\mathrm{C}$ vs $\mathrm{G}, \mathrm{D}$ vs $\mathrm{F}, \mathrm{D}$ vs $\mathrm{G}, \mathrm{E}$ vs $\mathrm{F}$ and $\mathrm{E}$ vs $\mathrm{G}$ (table 3 ). In the present study, the diameter of Islets of Langerhans increased up to 49 years of the age. The decreased diameter was found in the both extremities of life.

Table 2. Number of islets of Langerhans in the head, body and tail of the pancreas in different age group

\begin{tabular}{|c|c|c|c|}
\hline \multirow{2}{*}{$\begin{array}{l}\text { Group } \\
\text { (n) }\end{array}$} & \multicolumn{3}{|c|}{$\begin{array}{c}\text { Number of islets of Langerhans per unit area } \\
\text { of microscopic field }\end{array}$} \\
\hline & $\begin{array}{c}\text { Head } \\
\text { Mean } \pm \text { SD }\end{array}$ & $\begin{array}{c}\text { Body } \\
\operatorname{Mean} \pm \text { SD }\end{array}$ & $\begin{array}{c}\text { Tail } \\
\text { Mean } \pm \text { SD }\end{array}$ \\
\hline $\begin{array}{c}\text { A } \\
(5)\end{array}$ & $\begin{array}{l}1.40 \pm 0.55 \\
(1.0-2.0)\end{array}$ & $\begin{array}{c}1.20 \pm 0.45 \\
(1.0-2.0)\end{array}$ & $\begin{array}{c}2.40 \pm 0.55 \\
(2.0-3.0)\end{array}$ \\
\hline $\begin{array}{l}\mathrm{B} \\
(5)\end{array}$ & $\begin{array}{c}1.80 \pm 0.45 \\
(1.0-2.0)\end{array}$ & $\begin{array}{c}2.40 \pm 0.45 \\
(2.0-3.0)\end{array}$ & $\begin{array}{c}3.00 \pm 1.22 \\
(1.0-4.0)\end{array}$ \\
\hline $\begin{array}{c}\mathrm{C} \\
(5)\end{array}$ & $\begin{array}{l}1.40 \pm 0.55 \\
(1.0-2.0)\end{array}$ & $\begin{array}{c}2.00 \pm 0.00 \\
(2.0-2.0)\end{array}$ & $\begin{array}{c}2.40 \pm 1.34 \\
(1.0-4.0)\end{array}$ \\
\hline $\begin{array}{l}\mathrm{D} \\
(5)\end{array}$ & $\begin{array}{l}1.00 \pm 0.00 \\
(1.0-1.0)\end{array}$ & $\begin{array}{c}2.50 \pm 0.55 \\
(2.0-3.0)\end{array}$ & $\begin{array}{c}2.80 \pm 0.84 \\
(2.0-4.0)\end{array}$ \\
\hline $\begin{array}{c}E \\
(5)\end{array}$ & $\begin{array}{c}1.80 \pm 0.45 \\
(1.0-2.0)\end{array}$ & $\begin{array}{c}2.40 \pm 8.90 \\
(2.0-4.0)\end{array}$ & $\begin{array}{c}3.00 \pm 1.22 \\
(1.0-4.0)\end{array}$ \\
\hline $\begin{array}{c}\mathrm{F} \\
(5)\end{array}$ & $\begin{array}{c}1.00 \pm 0.00 \\
(1.0-1.0)\end{array}$ & $\begin{array}{c}2.20 \pm 0.45 \\
(2.0-3.0)\end{array}$ & $\begin{array}{c}2.80 \pm 0.84 \\
(2.0-4.0)\end{array}$ \\
\hline \multirow[t]{2}{*}{$\begin{array}{c}G \\
(5) \\
\end{array}$} & $\begin{array}{c}1.20 \pm 0.45 \\
(1.0-2.0)\end{array}$ & $\begin{array}{c}2.00 \pm 0.00 \\
(2.0-2.0)\end{array}$ & $\begin{array}{c}3.20 \pm 0.45 \\
(3.0-4.0)\end{array}$ \\
\hline & $\begin{array}{c}\text { Head } \\
\text { P value }\end{array}$ & $\begin{array}{c}\text { Body } \\
\text { P value }\end{array}$ & $\begin{array}{c}\text { Tail } \\
\text { P value }\end{array}$ \\
\hline A vs B & $>0.10$ & $<0.01$ & $>0.10$ \\
\hline A vs $C$ & $>0.50$ & $<0.05$ & $>0.50$ \\
\hline A vs D & $>0.10$ & $<0.001$ & $>0.50$ \\
\hline A vs E & $>0.10$ & $<0.01$ & $>0.10$ \\
\hline A vs F & $>0.10$ & $<0.01$ & $>0.50$ \\
\hline A vs $G$ & $>0.10$ & $<0.05$ & $>0.10$ \\
\hline $\mathrm{B}$ vs $\mathrm{C}$ & $>0.10$ & $>0.10$ & $>0.10$ \\
\hline B vs D & $<0.01$ & $>0.50$ & $>0.50$ \\
\hline $\mathrm{B}$ vs $\mathrm{E}$ & $>0.50$ & $>0.50$ & $>0.50$ \\
\hline B vs F & $<0.01$ & $>0.50$ & $>0.50$ \\
\hline B vs $G$ & $<0.05$ & $>0.10$ & $>0.50$ \\
\hline C vs D & $>0.10$ & $>0.50$ & $>0.50$ \\
\hline C vs E & $>0.10$ & $>0.10$ & $>0.10$ \\
\hline $\mathrm{C}$ vs F & $>0.10$ & $>0.50$ & $>0.50$ \\
\hline C vs $\mathrm{G}$ & $>0.10$ & $>0.50$ & $>0.10$ \\
\hline $\mathrm{D}$ vs $\mathrm{E}$ & $<0.01$ & $>0.50$ & $>0.50$ \\
\hline D vs F & $>0.50$ & $>0.10$ & $>0.50$ \\
\hline D vs $G$ & $>0.10$ & $>0.50$ & $>0.50$ \\
\hline E vs F & $<0.01$ & $>0.50$ & $>0.50$ \\
\hline E vs G & $<0.05$ & $>0.10$ & $>0.50$ \\
\hline F vs G & $>0.10$ & $>0.50$ & $>0.50$ \\
\hline
\end{tabular}


Figures in parentheses indicate range.

Table 3. Average diameter of islets of Langerhans of the pancreas in different age group

\begin{tabular}{|c|c|}
\hline $\begin{array}{l}\text { Group } \\
\text { (n) }\end{array}$ & $\begin{array}{c}\text { Average diameter of islets of } \\
\text { Langerhans }(\mu \mathrm{m}) \\
\text { Mean } \pm \text { SD } \\
\end{array}$ \\
\hline $\begin{array}{c}\mathrm{A} \\
(5)\end{array}$ & $\begin{array}{l}82.64 \pm 0.73 \\
(82.0-83.6)\end{array}$ \\
\hline $\begin{array}{l}\mathrm{B} \\
(5)\end{array}$ & $\begin{array}{l}96.32 \pm 0.91 \\
(94.8-97.2)\end{array}$ \\
\hline $\begin{array}{l}\mathrm{C} \\
(5)\end{array}$ & $\begin{array}{l}108.52 \pm 8.76 \\
(96.4-116.0)\end{array}$ \\
\hline $\begin{array}{l}\mathrm{D} \\
(5)\end{array}$ & $\begin{array}{c}135.20 \pm 8.38 \\
(126.8-144.8)\end{array}$ \\
\hline $\begin{array}{l}\mathrm{E} \\
(5)\end{array}$ & $\begin{array}{c}134.36 \pm 4.46 \\
(127.8-140.4)\end{array}$ \\
\hline $\begin{array}{l}\mathrm{F} \\
(5)\end{array}$ & $\begin{array}{c}102.40 \pm 0.89 \\
(101.2-103.6)\end{array}$ \\
\hline \multirow[t]{2}{*}{$\begin{array}{l}\mathrm{G} \\
(5) \\
\end{array}$} & $\begin{array}{c}97.20 \pm 2.00 \\
(95.2-100.0)\end{array}$ \\
\hline & P value \\
\hline A vs B & $<0.001$ \\
\hline A vs $C$ & $<0.001$ \\
\hline A vs D & $<0.001$ \\
\hline A vs E & $<0.001$ \\
\hline A vs F & $<0.001$ \\
\hline A vs $G$ & $<0.001$ \\
\hline $\mathrm{B}$ vs $\mathrm{C}$ & $<0.01$ \\
\hline B vs D & $<0.001$ \\
\hline $\mathrm{B}$ vs $\mathrm{E}$ & $<0.001$ \\
\hline $\mathrm{B}$ vs $\mathrm{F}$ & $>0.50$ \\
\hline B vs $G$ & $>0.50$ \\
\hline C vs D & $<0.001$ \\
\hline C vs E & $<0.001$ \\
\hline C vs F & $>0.50$ \\
\hline C vs $G$ & $<0.01$ \\
\hline D vs E & $>0.50$ \\
\hline $\mathrm{D}$ vs $\mathrm{F}$ & $<0.001$ \\
\hline D vs $G$ & $<0.001$ \\
\hline E vs F & $<0.001$ \\
\hline E vs G & $<0.001$ \\
\hline F vs G & $>0.10$ \\
\hline
\end{tabular}

Figures in parentheses indicate range.

\section{Discussion:}

Ross \& Pawlina ${ }^{4}$ stated that the islets constitute about $1-2 \%$ of the volume of the pancreas. Saito et al. ${ }^{14}$ found that the islet number per $\mathrm{mm}^{3}$ pancreatic volume varied with a wide range of 43.26 to 583.42 . Hellman ${ }^{15}$ reported that the number of the pancreatic islets in unit area of tissue in non-diabetic humans varied with the range of 10.6 to 43.8 , which was independent of age. Our values are roughly several times smaller than that of previous researchers. ${ }^{14,15}$

Soejima \& Landing ${ }^{16}$ found that the pancreatic islets in diabetes showed hypertrophy, where the mean volume/ diameter of the three largest pancreatic islets was $0.00795 \pm 0.00599 \mathrm{~mm}$, being larger than the normal. Mescher ${ }^{3}$ stated that the diameter of the islets ranges from 100 to $200 \mu \mathrm{m}$, which is in agreement with the present study. Karim ${ }^{17}$ reported the mean diameter of the islets in the head, body and tail of the pancreas were $110.628 \pm 3.615 \mu \mathrm{m}$, $97.736 \pm 6.270 \mu \mathrm{m}$ and $116.496 \pm 1.937 \mu \mathrm{m}$ respectively. Thus, the mean diameter of the islets in the tail of the pancreas was the largest and that in the body of the pancreas was the smallest. Murtaugh \& Melton ${ }^{18}$ mentioned that the islets contain an average of 3000 cells and range in diameter from 40 to $900 \mu \mathrm{m}$. Firoz ${ }^{19}$ found that the average diameter of the islets were $157.13 \pm 16.5 \mu \mathrm{m}$ in male and $145.23 \pm 18.5 \mu \mathrm{m}$ in female in group A (5-20 years), $166.07 \pm 17.29 \mu \mathrm{m}$ in male and $147.61 \pm 17.17 \mu \mathrm{m}$ in female in group B (21-40 years), $155.35 \pm 15.53 \mu \mathrm{m}$ in male and $149.10 \pm 18.91 \mu \mathrm{m}$ in female in group C (41-65 years). In the present study, the diameter of islets of Langerhans was found to be gradually increased with advancing of age up to 49 years, then decreases again. However, the number of cells and extent of diameter of islets were within the range described by Murtaugh \& Melton. ${ }^{18}$ Besides, the lowest mean diameter of islets of Langerhans was $82.64 \pm 0.73 \mu \mathrm{m}$ in A group (10-19 years) and highest was in $135.20 \pm 8.38 \mu \mathrm{m}$ in D group (40-49 years), which was similar to the findings of Karim, ${ }^{17}$ but much lower than that of Firoz. ${ }^{19}$ Dissimilarities mentioned above may attribute to racial variation and geographical distribution. The limitation of our study was that females were excluded due to less availability of the female cadaveric pancreas during study period.

\section{Conclusion:}

Only few variations were found in number of islets of Langerhans of the pancreas in its head and body regions, in relation to age. The number of the islets was much higher in tail than that of other regions. However, the diameter of the islets was found to increase up to 49 years and later decreased. Here, the decreased diameter was found in the both extremities of life. Further studies with lager samples and advanced stereological procedures in both normal and diabetic population and in both sexes are recommended.

\section{References:}

1. Glass J, Mundy AR. Abdomen and pelvis. In: 
Standring S, Ellis H, Healy JC, et al. eds. Gray's anatomy: the anatomical basis of clinical practice. $39^{\text {th }}$ ed. Edinburgh: Elsevier Churchill Livingstone; 2005.

2. Kumar V, Abbas AK, Fausto N, eds. Robbins and Cotran pathologic basis of disease. $7^{\text {th }}$ ed. New Delhi: Saunders; 2004.

3. Mescher AL. Junqueira's basic histology: text and atlas. $12^{\text {th }}$ ed. Baltimore: McGraw-Hill; 2010.

4. Ross MH, Pawlina W. Histology: a text and atlas with correlated cell and molecular biology. $5^{\text {th }}$ ed. Baltimore: Lippincott Williams \& Wilkins; 2006.

5. Kreel L, Sandin B. Changes in pancreatic morphology associated with ageing. Gut 1973;14:962-70.

http://dx.doi.org/10.1136/gut.14.12.962

6. Burghen GA, Murrell LR. Factors influencing isolation of islets of Langerhans. Diabetes 1989;38:129-32.

http://dx.doi.org/10.2337/diab.38.1.S129

7. Robertson RP. Islet transplantation as a treatment for diabetics- a work in progress. New Engl J Med 2004;350:694-705.

http://dx.doi.org/10.1056/NEJMra032425

8. Yeo ZX, Zhou DS. In vitro cultivation of human fetal pancreatic ductal stem cells and their differentiation into insulin-producing cells. World J Gastroenterol 2004;10:1452-6.

9. Kaihoh T, Masuda T, Sasano N, et al. The size and number of Langerhans islets correlated with their endocrine function: a morphometry on immunostained serial sections of adult human pancreases. Tohoku J Exp Med 1986;149:1-10.

http://dx.doi.org/10.1620/tjem.149.1

10. Gepts W. Islet changes in human diabetes. In: Cooperstein SJ, Watkins D, eds. The islets of Langerhans. New York: Academic Press; 1981.

11. von Mach MA, Schlosser J, Weiland M, et al. Size of pancreatic islets of Langerhans: a key parameter for viability after cryopreservation. Acta Diabetol
2003;40:123-9.

http://dx.doi.org/10.1007/s00592-003-0100-4

12. Varley PF, Rohrmann CA Jr., Silvis SE, et al. The normal endoscopic pancreatogram. Radiology 1976;118:295-300.

13. Wolfe-Coote SA, duToit DF. Distribution of cell types of the islets of Langerhans throughout the pancreas of the Chacma baboon. Anat Rec 1987;217:172-7.

http://dx.doi.org/10.1002/ar.1092170209

14. Saito K, Iwama N, Takahashi T. Morphometrical analysis on topographical difference of size distribution, number and volume of islets in the human pancreas. Tohoku J Exp Med 1978;124:17786.

http://dx.doi.org/10.1620/tjem.124.177

15. Hellman B. The frequency distribution of the number and volume of the iselts of Langerhans in man. I. Studies on non-diabetic adults. Acta Soc Med Ups 1959; 64: 432-60.

16. Soejima K, Landing BH. Pancreatic islets in older patients with cystic fibrosis with and without diabetes mellitus: morphometric and immunocytologic studies. Pediatr Pathol 1986;6:25-46.

http://dx.doi.org/10.3109/15513818609025923

17. Karim M. The study of the comparative anatomy of the pancreas in goats, cows and man [thesis]. Dhaka: IPGMR, University of Dhaka; 1994.

18. Murtaugh LC, Melton DA. Genes, signals, and lineages in pancreas development. Annu Rev Cell Dev Biol 2003;19:71-89.

http://dx.doi.org/10.1146/annurev. cellbio.19.111301.144752

19. Firoz A. Histological study of islets of Langerhans of human postmortem pancreas in Bangladeshi people. J Dhaka Natl Med Coll Hosp 2010;16:469. 